\title{
Transgene inheritances and genetic similarities of near isogenic lines of genetically modified common beans
}

\author{
Patrícia Valle Pinheiro(1), Josias Corrêa de Faria(1), Elsa Oliveira Paranaguá e Lago Nogueira(2) \\ and Francisco José Lima Aragão(2)
}

\begin{abstract}
(1)Embrapa Arroz e Feijão, Rodovia GO 462, Km 12 Zona Rural, Caixa Postal 179, CEP 75375-000 Santo Antônio de Goiás, GO E-mail: patricia@cnpaf.embrapa.br, josias@cnpaf.embrapa.br. (2)Embrapa Recursos Genéticos e Biotecnologia, PqEB W5 Norte (final), CEP 70770-900 Brasília, DF. E-mail: elsa@cenargen.embrapa.br, aragao@cenargen.embrapa.br
\end{abstract}

Abstract - The objective of the present work was to determine the inheritance and stability of transgenes of a transgenic bean line expressing the genes rep-trap-ren from Bean golden mosaic virus and the bar gene. Crosses were done between the transgenic line and four commercial bean cultivars, followed by four backcrosses to the commercial cultivars. Progenies from each cross were evaluated for the presence of the transgenes by brushing the leaves with glufosinate ammonium and by polymerase chain reaction using specific oligonucleotides. Advanced generations were rub-inoculated with an isolate of Bean common mosaic necrosis virus (BCMNV). The transgenes were inherited consistently in a Mendelian pattern in the four crosses studied. The analyzed lines recovered close to $80 \%$ of the characteristics of the recurrent parent, as determined by the random amplified DNA markers used, besides maintaining important traits such as resistance to BCMNV. The presence of the transgene did not cause any detectable undesirable effect in the evaluated progenies.

Index terms: Phaseolus, BCMNV, genetic engineering, genetic variability, transgene genotypic stability.

\section{Herança de transgenes e similaridade genética de linhagens quase isogênicas de feijoeiro-comum geneticamente modificado}

\begin{abstract}
Resumo - O objetivo do presente trabalho foi determinar a herança e a estabilidade de transgenes de uma linhagem de feijoeiro-comum com expressão dos genes rep-trap-ren, do Bean golden mosaic virus, e do gene bar. Foram realizados cruzamentos entre a linhagem transgênica e quatro cultivares comerciais de feijão, seguidos de quatro retrocruzamentos. As progênies de cada cruzamento foram avaliadas quanto à presença dos transgenes, com aplicação do glifosinato de amônia nas folhas e por meio da reação da polimerase em cadeia com uso de oligonucleotídeos específicos. O vírus do mosaico comum necrótico do feijoeiro, Bean common mosaic necrosis virus (BCMNV), foi inoculado mecanicamente nas gerações avançadas. Os transgenes foram herdados em padrão mendeliano nos quatro cruzamentos estudados. As linhagens analisadas apresentaram cerca de $80 \%$ das características do parental recorrente, conforme determinado por análises com uso de marcadores de DNA, além de manter caracteres importantes, tais como resistência ao BCMNV. A presença do transgene não causou efeitos indesejáveis que pudessem ser detectados nas progênies avaliadas.
\end{abstract}

Termos para indexação: Phaseolus, BCMNV, engenharia genética, variabilidade genética, estabilidade genotípica do transgene.

\section{Introduction}

Bean golden mosaic virus (BGMV) is the causal agent of one of the most important common bean viral diseases, responsible for yield losses of up to $100 \%$ in many bean growing areas of Brazil. Presently, the main management measure is the chemical control of the vector, the whitefly Bemisia tabaci Genn. The golden mosaic disease is a challenge for plant breeders, because no natural immunity or high level of disease resistance has been identified in genotypes of Phaseolus (Bianchini, 1999; Aragão et al., 2001; Morales \& Anderson, 2001). Partial resistance to Bean golden mosaic virus (BGMV) was obtained by genetically engineering of the common bean cultivar Olathe Pinto, using a construct to express the viral gene rep, a replication protein, with a single amino acid substitution (D262R), besides the genes trap and ren (Faria et al., 2006). The cassette also contained the gene bar as a marker gene which confers resistance to the herbicide glufosinate ammonium (GA). A BGMV and herbicide tolerant line (namely Olathe M 1/4) 
was obtained and shown to have stable inheritance and expression of the transgene, evaluated up to the $\mathrm{R}_{8}$ generation. Two copies of the transgene were detected in the Olathe M 1/4 line based on Southern blot analysis (Faria et al., 2006).

Mendelian inheritance patterns are typically observed in transgenic plants, independently of the method used for transformation (Soares et al., 2005; Anuradha et al., 2006; Faria et al., 2006; Yao et al., 2006; Sriskandarajah et al., 2007; Terakami et al., 2007). Atypical nonMendelian segregations of transgenes have also been reported in 10 to $50 \%$ of independent transgenic lines (Aragão et al., 1996; Yin et al., 2004; Romano et al., 2005). Stable inheritance pattern of a transgene depends on at least three factors: the nature of the recipient genome, the transgene, and their interaction (Yin et al., 2004; Romano et al., 2005). Transgene elimination and silencing can also explain some of the distortions observed in segregation of progenies, and are seen as defense mechanisms in some species (Romano et al., 2005; Zhang et al., 2006). There are reports on the progeny of certain lines that inherited only one or none of the copies of the transgene. In many cases, the transgenes were inserted in different loci, resulting in the integration of multiple copies in the plant genome (Aragão et al., 1996; Rooke et al., 2003; Huang \& Wei, 2005; Chaudhury et al., 2007). An insertional mutation of an essential gene required for ovule fertilization and development was indicated for aberrant inheritance of gus, neo, $A C 123$ and $B C l$ transgenes in common beans (Aragão et al., 1996).

Knowledge of the patterns of inheritance and genotypic stability of the transgenes in different genetic backgrounds is important to appropriately use the genetically modified organisms in agriculture. Several studies were carried out to analyze the inheritance of transgenes in primary transformants, and evaluated only the $\mathrm{R}_{0}$ and $\mathrm{R}_{1}$ generations (Butterfield et al., 2002; Rooke et al., 2003; Sriskandarajah et al., 2007; Terakami et al., 2007). Nevertheless, to safely verify if the inheritance of a transgene has a stable pattern, it is necessary to evaluate its segregation in different backgrounds for at least three generations. Schmidt et al. (2004) reported that transferring transgenes to distinct genetic backgrounds could lead to different gene expression levels. Analysis of the progenies of backcrosses can also be useful tools to verify if the traits of the recurrent parent could be normally recovered by the progenies and if the genes inserted could be accountable for any undesirable effect on the plant genome.

The objectives of the present work were to determine the inheritance and stability of the transgenes inserted in the Olathe M 1/4 after crossing with commercial cultivars, the genetic similarities between near isogenic lines (NILs) and their respective parents, and to evaluate if the gene for resistance to the Bean common mosaic necrosis virus (BCMNV), present in the recurrent parents, was maintained in the NILs without specific selection.

\section{Materials and Methods}

The genetically transformed line Olathe M1/4, used as donor parent of the transgene, contains two copies of the transgene in a single locus, and was obtained by particle bombardment from a linearized plasmid, after removing the ampicillin-resistance gene (Faria et al., 2006). The commercial cultivars Pérola, Timbó, Valente, and Diamante Negro, all belonging to the Meso-American gene pool, were chosen as parents to make crosses with Olathe M 1/4. They belong to the seed classes Carioca, Rosinha and Black (last two), respectively. To obtain near isogenic lines (NILs), initial crosses were made between the line Olathe M1/4 and the above named cultivars, followed by four backcrosses to the recurrent respective parent line. The commercial recurrent parent was always used as the female to facilitate the assurance that the actual crosses were successful.

All $F_{1}$ plants from the first cross were PCR-positive for the transgenes and had resistance to glufosinate ammonium what allowed them to be used as pollen donors to generate the first backcross $\left(\mathrm{BC}_{1} \mathrm{~F}_{1}\right) . \mathrm{BC}_{1} \mathrm{~F}_{1}$ plants were also verified for the presence of the transgenes by PCR analysis, and for their resistance to glufosinate ammonium (GA). After this, these plants were used as pollen donors to obtain $\mathrm{BC}_{2} \mathrm{~F}_{1}$, and so forth until the $\mathrm{BC}_{4} \mathrm{~F}_{1}$.

Resistance to glufosinate ammonium was verified through brushing the herbicide (Finale, $200 \mathrm{gL}^{-1}$ ) at $0.03 \%$ active ingredient on the primary leaves and observing eventual symptoms of injury two days later. In order to demonstrate that both bar and rep-trap-ren cassettes were linked, plants were also analyzed for the presence of the rep-trap-ren by PCR, according to 
Faria et al. (2006). The segregation of the transgenes in each progeny was compared to the expected Mendelian inheritance ratio by using a chi-square test.

The $F_{1}$ plants from $B_{4}$ were selected for the presence of the transgene, allowed to self, and then advanced until the $F_{6}$ generation by the single seed descent method. Seeds of an individual homozygous $F_{6}$ plant were increased before they could be taken to the experimental field in 2005 and 2006, for observations in relation to the recurrent parents, such as growth cycle, growth habit, and Bean golden mosaic virus incidence. Field experiments were carried out at Embrapa Arroz e Feijão (Santo Antônio de Goiás, GO, Brazil, at. $16^{\circ} 28^{\prime} 00^{\prime \prime S}, 49^{\circ} 17^{\prime} 00^{\prime \prime} \mathrm{W}$, alt. $823 \mathrm{~m}$ ), with permission from the Comissão Técnica Nacional de Biossegurança (CTNBio). In 2005, the transgenic lines $(35,31,44$ and 35 lines derived from cultivars Pérola, Timbó, Diamante Negro, and Valente, respectively), were sown in single 5-meter rows, interpolated at each five rows with the respective recurrent cultivar. Samples of foliar tissues were collected from one plant of each row and stored at $-20^{\circ} \mathrm{C}$ until processing. The most productive line from each cross was selected from this experiment, in order to evaluate the resistance to golden mosaic under field conditions, in 2006.

For Southern analysis, genomic DNA was isolated by using the DNeasy Plant Mini Kit (Qiagen, Valencia, CA, USA) and digested with XhoI. Southern blotting was carried out as previously described (Faria et al., 2006).

Genetic similarity analysis of the near isogenic lines was evaluated using RAPD (random amplified polymorphic DNA analysis) markers. Samples from $\mathrm{F}_{6}$ generation, previously analyzed for the presence of the transgenes, were used to carry out the RAPD analysis. An initial screening with 57 primers was done, and the most polymorphic ones were selected for each of the crosses with the line Olathe M1/4: 'Pérola' (OPA6, OPAD19, OPD3, OPF7, OPL6, OPL9, OPL19, OPM10, OPM12, OPM15 and OPM19), 'Valente' (OPA6, OPB5, OPF8, OPF15, OPJ5, OPJ16, OPL3, OPL6, OPL9, OPM19, OPP16 and OPW13), 'Timbó' (OPA6, OPAD12, OPF8, OPF12, OPF15, OPF16, OPJ16, OPL3, OPL6 and OPM12), and 'Diamante Negro' (OPA6, OPAD19, OPE6, OPE10, OPF16, OPJ5, OPJ16, OPL3, OPL19 and OPS13), giving a total number of 25 unique primers. Thirty-three NILs from each cross were evaluated besides the parent lines (line Olathe M 1/4, the respective commercial non transgenic recurrent cultivar, and the non transgenic cultivar Olathe Pinto). The amplification reactions for the RAPD analysis were performed in volumes of $13 \mu \mathrm{L}$, containing $1.3 \mu \mathrm{L}$ of the supplied polymerase buffer $\left(10 \mathrm{mmol} \mathrm{L}^{-1}\right.$ Tris- $\mathrm{HCl}, \mathrm{pH} 8.4,50 \mathrm{mmol} \mathrm{L}^{-1}$ $\mathrm{KCl}$ ), $3 \mathrm{mmol} \mathrm{L}^{-1} \mathrm{MgCl}_{2}, 200 \mu \mathrm{mol} \mathrm{L}^{-1}$ of each dNTP, $500 \mu \mathrm{g} \mathrm{mL}^{-1}$ purified BSA, $2.3 \mu \mathrm{mol} \mathrm{L}^{-1}$ of each primer, $1 \mathrm{U}$ Taq DNA Polymerase (Phoneutria, Belo Horizonte, Brazil) and $3.0 \mathrm{ng}$ of genomic DNA. A thermocycler Perkin Elmer model 9600 (Waltham, MA, USA) was used for all amplifications and programmed to complete 40 cycles $\left(1 \mathrm{~min}\right.$ at $94^{\circ} \mathrm{C}, 2 \mathrm{~min}$ at $35^{\circ} \mathrm{C}$, and $2 \mathrm{~min}$ at $72^{\circ} \mathrm{C}$ ), followed by a final extension of $5 \mathrm{~min}$ at $72^{\circ} \mathrm{C}$. Amplified DNA fragments were analyzed by electrophoresis on $1.5 \%$ agarose gel, stained with ethidium bromide, and photographed under ultraviolet light in gel documentation system.

Results were analyzed on the basis of presence or absence of amplified PCR products (DNA bands), which characterized a polymorphic marker in each line in a binary matrix. The genetic similarity between parents and NILs was estimated through a similarity matrix, calculated using the Jaccard coefficient, which is recommended for binary data of close individuals. The matrix generated with these estimates was used for grouping analysis to construct a dendrogram through UPGMA (unweighted pair group method using arithmetic averages) and SAHN (sequential, aglomerative, hierarchic and non overlapping clustering) methods. The cofenetic coefficients, which quantify the consistency of obtained clusters, were performed comparing the distance similarity matrix and the cofenetic similarity matrix. All statistical analyses were carried out using NTSYS version 2.02 (Rohlf, 1993).

The commercial cultivars used in the crosses with transgenic line Olathe M 1/4 have the dominant allele of the gene $I$, and express a systemic necrotic reaction in response to inoculation with the Bean vommon mosaic necrosis virus (BCMNV) strain NL3. The necrotic reaction to BCMNV is useful to identify genotypes with immunity to Bean common mosaic virus (BCMV) (Faria et al., 2000; Sartorato \& Faria, 2004). To evaluate if this specific trait was maintained in the NILs, the presence of the dominant allele of the gene $I$ was analyzed by inoculating the plants with BCMNV using the methodology described 
by Sartorato \& Faria (2004). The virus inoculum was maintained in infected seeds of the cultivar Rico 23, which were used as initial source of BCMNV since the virus is seed transmitted. Seedlings which were started fifteen days before sowing the NILs, displaying typical BCMNV symptoms were used as inocula. Thirty NILs were evaluated for each cross. Fifteen seeds from each NIL were treated with Carboxin $\left(66.7 \mathrm{~g} \mathrm{~L}^{-1}\right)+$ Thiram $\left(66.7 \mathrm{~g} \mathrm{~L}^{-1}\right)$ at a proportion of $600 \mathrm{~mL} 100 \mathrm{~kg}^{-1}$ of seeds, and were immediately sown in soil having fertilizer and covered with vermiculite. The parent lines were used as controls. One gram of young symptomatic leaves of Rico 23 was ground in $5 \mathrm{~mL}$ buffer $\left(0.01 \mathrm{~mol} \mathrm{~L}^{-1}\right.$ sodium and potassium phosphate buffer, $\mathrm{pH} 7.5$ ), and Carborundum 600 was used as abrasive. One of the primary leaves from the NILs plants was inoculated by gently rubbing with a gauze soaked in the crude extract. The other primary leaf was brushed with the herbicide GA $(0.03 \%$ a.i. $)$ to evaluate the presence of the bar gene.

Reaction of plants to the herbicide was evaluated two days later, while necrotic reaction to $\mathrm{BCMNV}$ was recorded three to four days after inoculation, by counting the numbers of plants which showed systemic necrotic reaction indicating the presence of the gene $I$. Fifteen days after inoculation, the presence of mosaic symptoms was evaluated for susceptible plants.

\section{Results and Discussion}

Polymerase chain reaction analysis and GA tolerance bioassays of all $F_{1}$ plants obtained indicated that the crosses between Olathe M 1/4 and the commercial cultivars were successful. For the $F_{1}$ generation of the backcrosses, deviations from the expected ratio values (1:1) for the presence:absence of transgenes were observed in few cases, probably indicating self-pollination rather than crossing. However, these results did not affect the next backcross step, because non transgenic plants were discarded from the program. Representative results of transgene segregation are shown in Table 1. All chi-square values indicated that the expected Mendelian 3:1 ratio (transgenic to non transgenic plants), for a single dominant locus, was observed at the $\mathrm{BC}_{2} \mathrm{~F}_{2}$ and $\mathrm{BC}_{4} \mathrm{~F}_{2}$ generations, for the four crosses.

The varied seed color genotypes used as female parents had no negative effect on the recovery of transgenic NILs transmitting the two transgenic traits. As discussed by Butterfield et al. (2002), using transgenic lines as parents in breeding programs would avoid the requirement for several years of field evaluation (if new events would have to be created), to ensure that the introduced gene is stably expressed and that no undesirable phenotypic effects were induced by the transgene. Heeres et al. (1997) also reported the transferring of transgenes from transgenic potato clones in a breeding program, and they concluded that the transgenic hybrid plants behaved just like non transgenic plants, except for the introduced trait. These authors also indicated that these results are important, since as long as transgenic plants have the same behavior of non transgenic plants, they could be considered safe to the environment.

According to Travella et al. (2005) and $\mathrm{Li}$ et al. (2007), genetic transformation via particle bombardment presents some disadvantages, such as unstable inheritance and expression of the transgene, besides the possible integration of a high number of copies of the transgene in the plant genome. The present work differed from those in many aspects, because although our transgenic line was obtained via particle bombardment, only two copies of the transgene were integrated (as a single locus) in the plant genome, and the transgene inheritance followed the Mendelian pattern, with apparently stable expression, in all the crosses with commercial cultivars.

Table 1. Genetic analysis of segregation for the genes rep-trap-ren and bar, in $\mathrm{F}_{2}$ population after the second backcross $\left(\mathrm{BC}_{2} \mathrm{~F}_{2}\right)$ and after the fourth backcross $\left(\mathrm{BC}_{4} \mathrm{~F}_{2}\right)$ to the commercial parent.

\begin{tabular}{lcccccccccc}
\hline Commercial Parent & \multicolumn{2}{c}{ All plants } & \multicolumn{2}{c}{ Resistant $^{(1)}$} & \multicolumn{2}{c}{ Susceptible } & \multicolumn{2}{c}{$\chi^{(2)}$} & \multicolumn{2}{c}{$\mathrm{p}^{(3)}$} \\
\cline { 2 - 10 } & $\mathrm{BC}_{2} \mathrm{~F}_{2}$ & $\mathrm{BC}_{4} \mathrm{~F}_{2}$ & $\mathrm{BC}_{2} \mathrm{~F}_{2}$ & $\mathrm{BC}_{4} \mathrm{~F}_{2}$ & $\mathrm{BC}_{2} \mathrm{~F}_{2}$ & $\mathrm{BC}_{4} \mathrm{~F}_{2}$ & $\mathrm{BC}_{2} \mathrm{~F}_{2}$ & $\mathrm{BC}_{4} \mathrm{~F}_{2}$ & $\mathrm{BC}_{2} \mathrm{~F}_{2}$ & $\mathrm{BC}_{4} \mathrm{~F}_{2}$ \\
\hline Pérola & 47 & 57 & 39 & 47 & 8 & 10 & 1.596 & 1.690 & 0.21 & 0.19 \\
Diamante Negro & 48 & 60 & 37 & 44 & 11 & 16 & 0.111 & 0.089 & 0.74 & 0.77 \\
Valente & 45 & 60 & 34 & 43 & 11 & 17 & 0.007 & 0.356 & 0.93 & 0.55 \\
Timbó & 42 & 45 & 32 & 33 & 10 & 12 & 0.032 & 0.067 & 0.86 & 0.80 \\
\hline
\end{tabular}

${ }^{(1)}$ Glufosinate ammonium-resistant and PCR-positive to the transgene rep plants. ${ }^{(2)}$ Glufosinate ammonium-susceptible and PCR-negative to the transgene rep plants. ${ }^{(3)}$ Probability that observed rations reflect the expected segregation ratio of $3: 1 . \chi^{2}$, qui-square. 
The transgenes were detected by the tolerance reaction to GA (given by the lack of toxic symptoms or a slight tissue damage from which the plant completely recovered). All plants with the transgene rep-trap-ren detected by PCR were also tolerant to GA, indicating the presence and expression of the bar gene (Table 1). Similar results were reported by Okada et al. (2002), who evaluated the offspring from crosses between transgenic $\left(\mathrm{R}_{0}\right.$ lines) and non transgenic sweet potato. Kiihl \& Arias (2008) worked with a soybean line expressing the gene ahas, and also concluded that the resistance to imazapyr was inherited and adequately expressed in the ten genotypes recipients of the transgene.

In the present work, all of the selections were based on herbicide-tolerance (besides PCR of the rep-trap-ren genes), during the backcross steps to transfer the cassettes bar and rep-trap-ren from Olathe M 1/4 to other cultivars. Disease incidence in both years was low to moderate, and, therefore, did not allow of differences between transgenic and conventional lines. The herbicide-resistance level from the original transgenic line seems to have been kept in all of the isolines, independently of the cross made.

Southern blot analysis showed the presence of two copies of the transgene in the analyzed $\mathrm{BC}_{4} \mathrm{~F}_{6}$ plants, as it was previous observed in the first eight generations of the original transformed plant (Faria et al., 2006). The two copies of the gene rep integrated in the plant genome, in association with the segregation in the offspring obeying the 3:1 ratio (transgenic:non transgenic) for a single gene, strongly indicate that the two copies are in a single locus. The same pattern was confirmed in all of the crosses between Olathe M 1/4 and the four commercial cultivars, suggesting that there was no recombination in the sequence of the transgene rep-trap-ren (Figure 1). Similar results were obtained by Chaudhury et al. (2007), who registered the integration of two copies of the transgene in the genome of cowpea, where the transgene segregated in a 3:1 Mendelian pattern. In addition, Okada et al. (2002) did not observe altered pattern of segregation, when they had multiple copies of the transgene introduced into the genome of sweet potato, also suggesting that the copies were inserted in a single locus.

A total of 300 RAPD loci, varying from 200 to 3.000 $\mathrm{bp}$ in length, were amplified by the 25 primers used in the analysis of the progenies resulting from the four crosses. From these RAPD loci 91 were polymorphic (30.3\%), indicating reasonable similarity between the NILs and their respective parent. The total number of polymorphic bands varied from three to 15 in all evaluated crosses.

In the cross Olathe $M \quad 1 / 4$ x Pérola, 90 loci were amplified using 11 primers, with band length varying from 200 to $1.800 \mathrm{bp}$ and showing $31.5 \%$ of polymorphisms for NILs. The numbers of amplified bands varied from seven (OPL9) to 15 (OPM19). Figure 2 shows that the progenies had the same

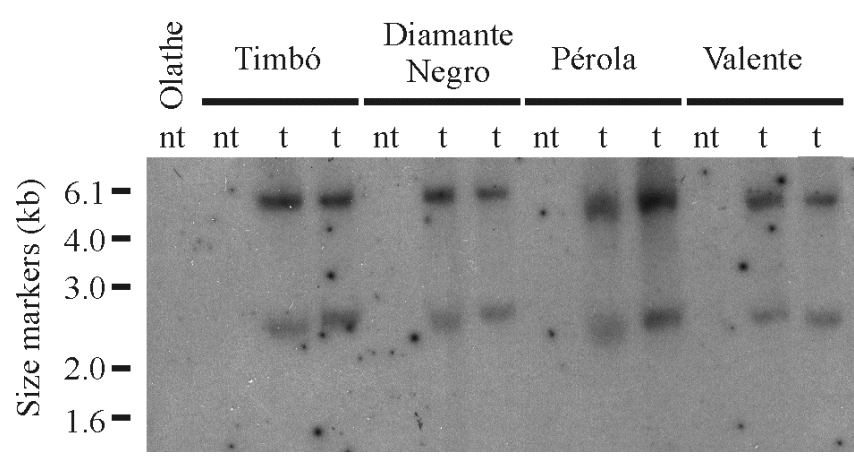

Figure 1. Southern analysis to detect the cassette reptrap-ren in the $\mathrm{BC}_{4} \mathrm{~F}_{5}$ generation plants. The genetically transformed line Olathe M 1/4 was crossed with the commercial cultivars Timbó, Diamante Negro, Pérola and Valente. nt, nontransgenic plants; $t$, transgenic plants.

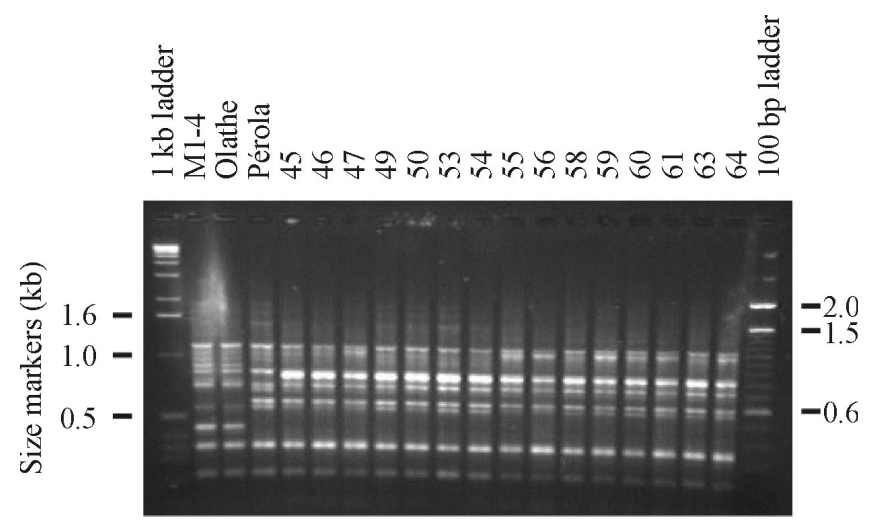

Figure 2. Typical agarose gel obtained to identify polymorphic RAPD markers, in the progeny of the cross between 'Olathe M 1/4' and 'Pérola', using the primer OPL6. Lane 1: $1 \mathrm{~kb}$ molecular weight marker; Lane 2: transgenic line Olathe M 1/4; Lane 3: nontransgenic cultivar Olathe Pinto; Lane 4: nontransgenic cultivar Pérola; Lanes 5-19: progenies. Lane 20: $100 \mathrm{bp}$ molecular weight marker. 
amplification pattern as the recurrent parent ('Pérola'), characterized by the presence of the same polymorphic specific bands in all individuals of the progeny, while those specific bands of the donor parent ('Olathe
M1/4') were lacking in the progenies. Three distinct groups were observed in the similarity dendrogram (Figure $3 \mathrm{~A}$ ). The first one clusters were 'Pérola' and line 45; the second clusters were all other isolines;
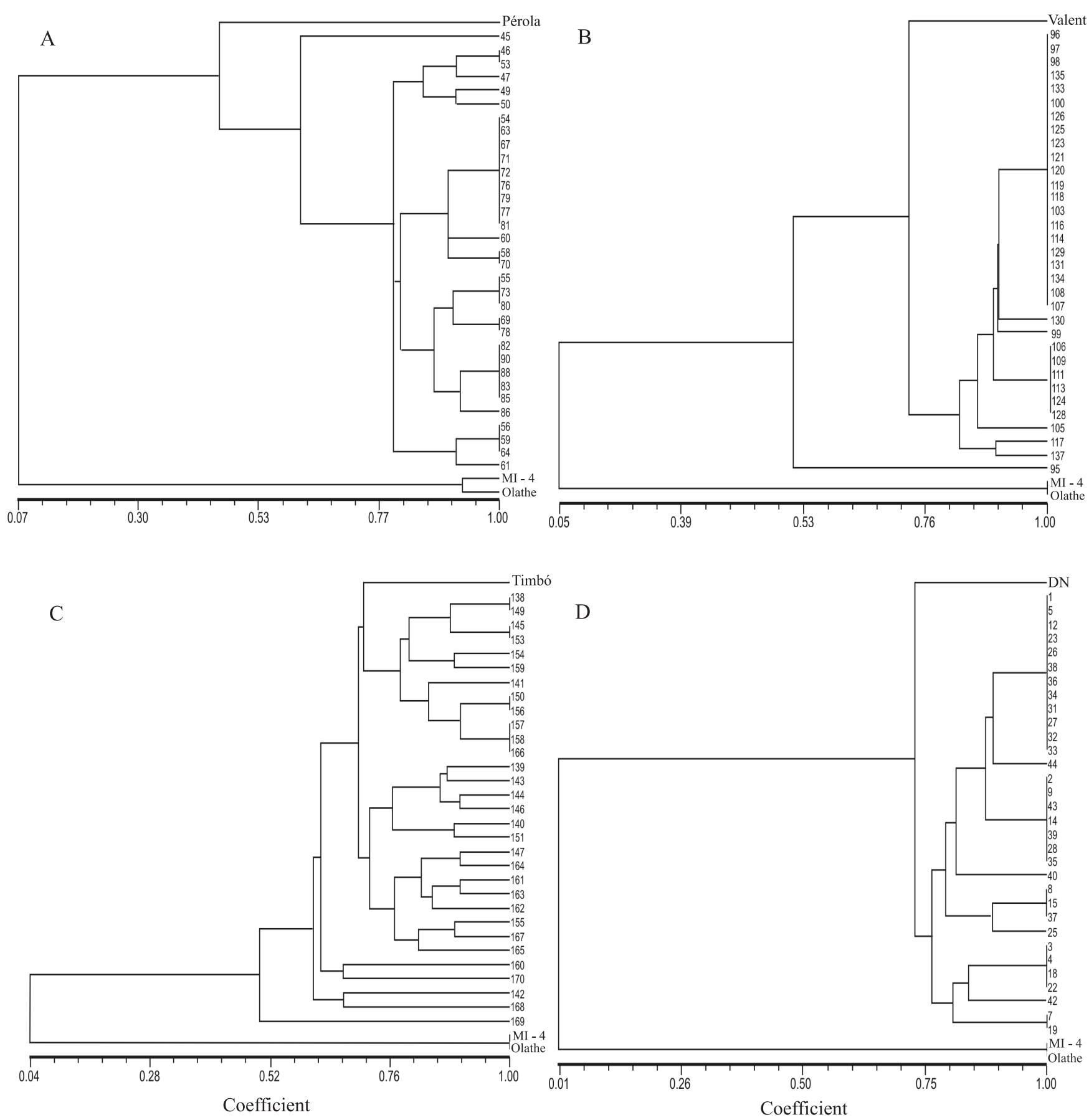

Figure 3. Dendrogram for the near isogenic lines from the four crosses between 'Olathe M 1/4' and the commercial bean cultivars. A, Cultivar Pérola $(n=36)$, cofenetic correlation coefficient $=0.98 ; B$, 'Valente' $(n=36)$, cofenetic correlation coefficient $=0.99 ;$ C, 'Timbó' $(n=34)$, cofenetic correlation coefficient $=0.93 ; \mathrm{D}$, 'Diamante Negro' $(n=35)$, cofenetic correlation coefficient $=0.97$. 
and, the third clusters were 'Olathe M1/4' and 'Olathe Pinto'.

For the NILs from the cross 'Olathe M1/4' $\mathrm{x}$ 'Valente', 86 loci were amplified using 12 primers. Band length varied from 300 to $1.500 \mathrm{bp}$ and had $29 \%$ of polymorphism. Number of amplified bands varied from five (OPW13) to 13 (OPJ16). Three major groups were observed in the dendrogram (Figure $3 \mathrm{~B}$ ). The first group clustered most NILs with the recurrent parent ('Valente'), showing over $80 \%$ of similarity; the second group placed the NIL 95 apart; and the third group consisted of 'Olathe M 1/4' and 'Olathe pinto'.

In the cross 'Olathe M 1/4' x 'Timbó', 69 RAPD loci were amplified. From these amplified bands, only $29.3 \%$ were polymorphic. The number of amplified bands varied from four (OPA6) to 11 (OPF12 e OPL6), and their length varied from 400 to $3.000 \mathrm{bp}$. Three groups were formed in the similarity dendrogram (Figure $3 \mathrm{C}$ ), joining the recurrent parent and most of the isolines to one branch with over $72 \%$ of similarity; 'Olathe Pinto' and the line 'Olathe M 1/4' formed one cluster, while NIL 169 stood alone, but closer to 'Olathe Pinto'.

For the NILs from the cross 'Diamante Negro' $x$ 'Olathe M 1/4', 55 RAPD loci were amplified using ten primers, with a length varying from 400 to 2.500 bp. From these markers $36.3 \%$ were polymorphic. The number of amplified bands varied from three (OPJ5) to 11 (OPL19). Two groups were formed in the similarity dendrogram (Figure $3 \mathrm{D}$ ): the first one contained the cultivar Olathe Pinto and line Olathe M 1/4, and the second one had the recurrent parent
('Diamante Negro') and the derived NILs, showing over $80 \%$ of similarity.

Similarity analysis between progenies and the respective recurrent parents showed that most characteristics were successfully recovered after four backcrosses. However, the level of similarity observed between progenies and recurrent parents was below the expected rate of $96.9 \%$ after four backcrosses. This occurred probably because backcrosses were carried out using $F_{1}$ plants as donors of pollen without genotypic (except for the transgenes) or phenotypic selection for the recurrent parents traits. Besides, using RAPDs may have a problem that the diversity is measured in the absence of information on what regions of the genome they represent and map. If the RAPDs cluster, as may well be the case, then they would be overrepresenting the actual variability, compared to markers which would be distributed throughout the genome. Additionally, no undesirable effect was observed due to the presence of the transgenes on the evaluated NILs, such as the nitrogen fixation capability. Again, in the present work, the traits reported were the resistance to BCMNV and to GA, but besides recovering more than $80 \%$ of the genetic background of recurrent parents, all of them had the commercial traits such as seed color, plant height, cycle, leaf size and shape. As Heeres et al. (2002) pointed out for transgenic potato, transgenic plants should be as similar as possible to their parents, differing from them mainly or perhaps only in the trait encoded by the introduced gene. This was the case in the current work.

The cultivars Pérola, Timbó, Valente and Diamante Negro showed hypersensitive reaction to BCMNV

Table 2. Number of near isogenic lines, obtained from the crosses between commercial cultivars and the transgenic line Olathe M 1/4, showing systemic necrosis reaction symptoms induced by Bean common mosaic necrosis virus (BCMNV) and slight damage by glufosinate ammonium.

\begin{tabular}{|c|c|c|c|}
\hline Evaluated lines and cultivars & $\begin{array}{c}\text { Systemic necrosis reaction } \\
\text { symptoms }{ }^{(1)}\end{array}$ & $\begin{array}{l}\text { Mosaic syptoms } \\
\text { (n⿳⿲丶丶㇒一 }{ }^{\circ} \text { of plants) }\end{array}$ & $\begin{array}{c}\text { Herbicide sensivity } \\
\left(\mathrm{n}^{\mathrm{o}} \text { of plants }\right)^{(2)}\end{array}$ \\
\hline$\overline{\text { Pérola }}$ & $27 / 27$ & 0 & $27 *$ \\
\hline Lines ('Pérola' x 'Olathe M 1/4') & $430 / 430$ & 0 & $20 * *$ \\
\hline Valente & $28 / 28$ & 0 & $28^{*}$ \\
\hline Lines ('Valente' x 'Olathe M 1/4') & $402 / 402$ & 0 & $12 * *$ \\
\hline Timbó & $15 / 15$ & 0 & $12 *$ \\
\hline Lines ('Timbó' x 'Olathe M 1/4') & $367 / 367$ & 0 & $42 * *$ \\
\hline Diamante Negro & $30 / 30$ & 0 & $30 *$ \\
\hline Lines ('Diamante Negro' x 'Olathe M 1/4') & $367 / 367$ & 0 & $4 * *$ \\
\hline Olathe Pinto & $0 / 12$ & 12 & $12^{*}$ \\
\hline Olathe M $1 / 4$ & $0 / 8$ & 8 & 0 \\
\hline
\end{tabular}


strain NL3, which resulted in systemic necrosis reaction (Table 2). This hypersensitive reaction is taken as an indication for the presence of the dominant allele $I$. The gene $I$ was present in all plants from all isolines analyzed, indicating the efficient recovery of this single dominant gene from the recurrent parent utilized. All of the evaluated NILs showed the same level of resistance to BCMNV as the recurrent parents displaying the systemic necrosis reaction. The susceptible control lines (Olathe Pinto and Olathe $\mathrm{M}$ 1/4) gave typical mosaic symptoms of BCMNV.

All non transgenic plants were sensitive to the applied herbicide. Some transgenic NILs had plants with slight damage caused by the herbicide, such as NILs 50, 55 and 58 (from 'Pérola') and 14 and 18 (from 'Diamante Negro') (Table 2), but not enough to sustain damage as in the controls. This may have occurred because a higher concentration of the herbicide solution was left in a single point of the leaf, due to the brushing method utilized. In other experiments, where this phenomenon was observed, the plants recovered from the damage, while non transgenic plant tissues died in the herbicide brushed area. In the present experiment, as there was a hypersensitive reaction to BCMNV and, consequently, death of these plants, it was not possible to observe if the herbicide-injured tissues would recover.

Genetic transformation methods enable inserting some traits that would not be possible to incorporate by traditional breeding methods, because of species incompatibility or even because of the absence of a desirable trait in the species genome. In some cases, genetic engineering can produce more efficient plants, as the transgenic line of the ornamental Campanula carpatica, obtained by Sriskandarajah et al. (2007), which was tolerant to ethylene. These authors observed that in one of these transgenic lines, flowers were produced over 27 days after exposure to ethylene, while the controls stopped flowering in just three days.

This work is the first report on transferring transgenes to commercial cultivars of $P$. vulgaris with analysis aiming at the recovery of recurrent parent traits. The stable transmission of transgenes from parents to offspring will make it possible to include this transgenic line as a donor parent in breeding programs, avoiding the burden of transformation of additional cultivars. Western analysis for the rep protein expression was shown for up to the $8^{\text {th }}$ generation plant of 'Olathe M $1 / 4^{\prime}$ (Faria et al., 2006).

\section{Conclusions}

1. The technology of transgenic crops may result in stable transformation.

2. The transgenic trait is inherited in a Mendelian way, as evaluated by multiple backcrosses and selfings.

3 . The presence of the transgenes does not cause any detectable undesirable effect in the evaluated progenies.

\section{Acknowledgements}

To Vanderlino Moreira de Santana, for the technical support in the greenhouse and field experiments; to Financiadora de Estudos e Projetos, for financial support.

\section{References}

ANURADHA, T.S.; JAMI, S.K.; DATLA, R.S.; KIRTI, P.B. Genetic transformation of peanut (Arachis hypogea L.) using cotyledonary node as explant and a promoterless gus:nptII fusion gene based vector. Journal of Biosciences, v.31, p.235-246, 2006.

ARAGÃO, F.J.L.; BARROS, L.M.G.; BRASILEIRO, A.C.M.; RIBEIRO, S.G.; SMITH, F.D.; SANFORD, J.C.; FARIA, J.C.; RECH, E.L. Inheritance of foreign genes in transgenic bean (Phaseolus vulgaris L.) co-transformed via particle bombardment. Theoretical and Applied Genetics, v.93, p.142-150, 1996.

ARAGÃO, F.J.L.; VIANNA, G.R.; ALBINO, M. das M.C.; DIAS, B.B.A.; FARIA, J.C. Transgênico resistente a Geminivirus. Biotecnologia, Ciência e Desenvolvimento, v.3, p.22-26, 2001.

BIANCHINI, A. Resistance to Bean Golden Mosaic Virus in bean genotypes. Plant Disease, v.83, p.615-620, 1999.

BUTTERFIELD, M.K.; IRVINE, J.E.; VALDEZ-GARZA, M.; MIRKOV, T.E. Inheritance and segregation of virus and herbicide resistance transgenes in sugarcane. Theoretical and Applied Genetics, v.104, p.797-803, 2002.

CHAUDHURY, D.; MADANPOTRA, S.; JAIWAL, R.; SAINI, R.; KUMAR,P.A.;JAIWAL,P.K.Agrobacterium tumefaciens-mediated high frequency genetic transformation of an Indian cowpea [Vigna unguiculata (L.) Walp.] cultivar and transmission of transgenes into progeny. Plant Science, v.172, p.692-700, 2007.

FARIA, J.C.; ALBINO, M.M.C.; DIAS, B.B.A.; CUNHA, N.B.; SILVA, L.M.; VIANNA, G.R.; ARAGÃO, F.J. L. Partial resistance to Bean Golden Mosaic Virus in a transgenic common bean (Phaseolus vulgaris L.) line expressing a mutated rep gene. Plant Science, v.171, p.565-571, 2006.

FARIA, J.C.; DEL PELOSO, M.J.; CARNEIRO, G.E.S. Resistência de cultivares de feijoeiro ao vírus do mosaico comum necrótico. Fitopatologia Brasileira, v.25, p. 197-199, 2000.

HEERES, P.; JACOBSEN, E.; VISSER, R.G.F. Behaviour of genetically modified amylose-free potato clones as progenitors in a breeding program. Euphytica, v.98, p.169-175, 1997. 
HEERES, P.; SCHIPPERS-ROZENBOOM， M.; JACOBSEN, E.; VISSER, R.G.F. Transformation of a large number of potato varieties: genotype-dependent variation in efficiency and somaclonal variability. Euphytica, v.124, p.13-22, 2002.

HUANG, X.Q.; WEI, Z.M. Successful Agrobacterium-mediated genetic transformation of maize elite inbred lines. Plant Cell, Tissue and Organ Culture, v.83, p.187-200, 2005.

KIIHL, T.A.M.; ARIAS, C.A.A. Soybean cultivar BR-16-AHAS tolerance to the herbicide imazapyr. Pesquisa Agropecuária Brasileira, v.43, p.1031-1035, 2008.

LI, S.H.; LI, J.; WANG, N.L.; WANG, Y.S.; YANG, G.X.; FANG, J.Y.; HE, G.Y. Inheritance and expression of copies of transgenes 1Dx5 and $1 \mathrm{Ax} 1$ in elite wheat (Triticum aestivum L.) varieties transferred from transgenic wheat through conventional crossing. Acta Biochimica et Biophysica Sinica, v.39, p.377-383, 2007.

MORALES, F.J.; ANDERSON, P.K. The emergence and dissemination of whitefly-transmitted geminiviruses in Latin America. Archives of Virology, v.146, p.415-441, 2001.

OKADA, Y.; NISHIGUCHI, M.; SAITO, A.; KIMURA, T.; MORI, M.; HANADA, K.; SAKAI, J.; MATSUDA, Y.; MURATA, T. Inheritance and stability of the virus-resistant gene in the progeny of transgenic sweet potato. Plant Breeding, v.121, p.249-253, 2002.

ROHLF, F.J. NTSYS-pc: numerical taxonomy and multivariate system. Version 2.9. New York: Applied Biostatistics, 1993.

ROMANO, E.; SOARES, A.; PROITE, K.; NEIVA, S.; GROSSI, M.; FARIA, J.C.; RECH, E.L.; ARAGÃO, F.J.L. Transgene elimination in genetically modified dry bean and soybean lines. Genetics and Molecular Research, v.4, p.177-184, 2005.

ROOKE, L.; STEELE, S.H.; BARCELO, P.; SHEWRY, P.R.; LAZZERI, P.A. Transgene inheritance, segregation and expression in bread wheat. Euphytica, v.129, p.301-309, 2003.
SARTORATO,A.; FARIA, J.C. Resistência de cultivares de feijoeiro ao vírus do mosaico comum necrótico. Summa Phytopathologica, v.30, p.394-397, 2004.

SCHMIDT, M.A.; MARTIN, G.S.; ARTELT, B.J.; PARROTT, W.A. Increased transgene expression by breeding and selection in white clover. Crop Science, v.44, p.963-967, 2004.

SOARES, A.; ROMANO, E.; NEIVA, S.; DE CAPDEVILLE, G.; VIANNA, G.R.; RECH, E.L.; ARAGÃO, F.J.L. Inheritance of a recessive transgene-associated character controlling albinism in transgenic bean (Phaseolus vulgaris L.). Plant Biology, v.7, p.104-108, 2005.

SRISKANDARAJAH, S.; MIBUS, H.; SEREK, M. Transgenic Campanula carpatica plants with reduced ethylene sensitivity. Plant Cell Reports, v.26, p.805-813, 2007.

TERAKAMI, S.; MATSUDA, N.; YAMAMOTO, T.; SUGAYA, S.; GEMMA, H.; SOEJIMA, J. Agrobacterium-mediated transformation of the dwarf pomegranate (Punica granatum L. var. nana). Plant Cell Reports, v.26, p.1243-1251, 2007.

TRAVELLA, S.;ROSS, S.M.;HARDEN,J.;EVERETT,C.;SNAPE, J.W.; HARWOOD, W.A. A comparison of transgenic barley lines produced by particle bombardment and Agrobacterium-mediated techniques. Plant Cell Reports, v.23, p.780-789, 2005.

YAO, Q.; CONG, L.; WANG, Y.S.; CHEN, M.J.; YANG, G.X.; HE, G.Y. Inheritance of the foreign gene 1Ax1 in transgenic wheat (Triticum aestivum L.) with gene cassettes lacking vector backbone sequences. Hereditas, v.28, p.695-698, 2006.

YIN, Z.; PLADER, W.; MALEPSZY, S. Transgene inheritance in plants. Journal of Applied Genetics, v.45, p.127-144, 2004.

ZHANG, Y.; YANG, B.Y.; CHEN, S.Y. Inheritance analysis of herbicide-resistant transgenic soybean lines. Acta Genetica Sinica, v.33, p.1105-1111, 2006.

$\overline{\text { Received on May 29, } 2009 \text { and accepted on August 15, } 2009}$ 